\title{
ANALISIS RISIKO KECELAKAAN LALU LINTAS BERDASAR TIPE KEPRIBADIAN DAN PELANGGARAN PADA PENGENDARA SEPEDA MOTOR
}

\author{
Defia Rosalina Anwar \\ Departemen Epidemiologi, Fakultas Kesehatan Masyarakat \\ Universitas Airlangga, Surabaya, Jawa Timur Indonesia \\ Email: deaa.rosalina@yahoo.co.id
}

\begin{abstract}
It is reasonable that the traffic accident increased because of the massive motor vehicle accident. WHO recorded that the traffic accident was the third most enormous killer after tuberculosis and coronary heart disease. The majority of motorcyclist is teenager that causes the increase of traffic accident. This research was conducted to acknowledge the relation between the type of personality and the violation of motorcyclist toward the traffic accident occurred to senior high school student. This research was analytical observation using two stage random sampling method. The population of the research was all student in Sampang regency in 2017. It was involving 127 respondents. The variables applied were the type of personality and the violation of motorcyclist (including traffic sign and road markings). The data was analysed by Chi Square and suggested that $(\alpha=0.05)$ the type of personality $(p=0.537 ; R R$ 1.457), and the violation of the motorcyclist ( $p=1 ; R R$ 0.930) have no significant relation to the traffic accident among senior high school student. The conclusion of this research is there is no relationship between personality type, violation by motorcycle with the incident of traffic accident. It is suggested to high school students not to drive a motor vehicle if they do not have a driver's license, in order to minimize the occurrence of traffic accidents.
\end{abstract}

Keywords: traffic accidents, high school students, personality type, breach of motor rider

\begin{abstract}
ABSTRAK
Banyaknya kendaraan bermotor merupakan salah satu penyebab meningkatnya angka kecelakaan lalu lintas. Menurut data dari WHO, kecelakaan lalu lintas merupakan pembunuh terbesar ketiga setelah penyakit tuberculosis dan jantung koroner. Pengendara motor yang mayoritas merupakan anak remaja juga menjadi penyebab tertinggi adanya kecelakaan lalu lintas. Penelitian ini dilakukan untuk mengetahui hubungan tipe kepribadian, dan pelanggaran oleh pengendara sepeda motor terhadap kejadian kecelakaan lalu lintas pada siswa SMA. Jenis penelitian yang dilakukan yaitu observasional analitik, serta menggunakan metode two stage random sampling. Populasi penelitian ini adalah seluruh siswa SMA di Kabupaten Sampang Tahun 2017. Besar sampel responden dalam penelitian ini sebanyak 107 responden. Variabel yang diteliti adalah tipe kepribadian dan pelanggaran yang dilakukan oleh pengendara sepeda motor, meliputi melanggar rambu larangan, dan marka jalan. Hasil analisis dengan menggunakan uji chi square $(\alpha=0,05)$ menunjukkan bahwa tipe kepribadian $(\mathrm{p}=0,537$; RR 1,457$)$, dan pelanggaran oleh pengendara sepeda motor $(\mathrm{p}=1 ; \mathrm{RR} 0,930)$ tidak mempunyai hubungan yang signifikan terhadap kejadian kecelakaan lalu lintas pada siswa SMA pengendara sepeda motor di Kabupaten Sampang Tahun 2017. Kesimpulan dari penelitian ini adalah tidak ada hubungan antara tipe kepribadian, pelanggaran oleh sepeda motor dengan kejadian kecelakaan lalu lintas. Disarankan kepada siswa SMA agar tidak mengendarai kendaraan bermotor jika belum memiliki SIM, agar meminimalisir terjadinya kecelakaan lalu lintas.
\end{abstract}

Kata kunci: kecelakaan lalu lintas, siswa SMA , tipe kepribadian, pelanggaran, pengendara sepeda motor 


\section{PENDAHULUAN}

Menurut World Health Organization (WHO) yang dimuat di Global Report on Road Safety, menjelaskan sebanyak 1,25 juta orang menjadi korban dari kecelakaan lalu lintas dan setiap tahunnya sebanyak 20-50 juta orang mengalami luka akibat kecelakaan lalu lintas. WHO juga menyebutkan bahwa kematian anak di dunia dapat disebabkan karena terjadinya kecelakaan lalu lintas. Rata-rata setiap harinya terjadi 1000 kematian pada rentang usia 10-24 tahun. Selain itu 54\% penyumbang kematian karena kecelakaan lalu lintas di dunia berasal dari Negara berpenghasilan menengah dan rendah.

Berdasarkan data dari Kepolisian Republik Indonesia, banyaknya kecelakaan lalu lintas berdasarkan jenis kendaraannya, sepeda motor merupakan kendaraan yang menduduki peringkat utama penyumbang kejadian kecelakaan lalu lintas terbanyak yaitu sebesar 108.883 kasus, sedangkan peringkat kedua ditempati oleh mobil penumpang sebanyak 18.147 kasus, mobil beban sebanyak 19.242 kasus, bus 4.808 kasus, dan kendaraan khusus sebanyak 1.050 kasus. Hal tersebut dapat disebabkan karena kurangnya kesadaran pada pengendara sepeda motor tentang bagaimana berkendara yang aman yang dapat mengurangi terjadinya risiko kecelakaan lalu lintas.

Besarnya angka kecelakaan oleh kendaraan sepeda motor juga berpengaruh terhadap jumlah korban jiwa di Indonesia. Selama tahun 2013, korban kecelakaan yang meninggal dunia sebanyak 26.416 jiwa, sementara itu untuk tahun 2014 jumlah korban meninggal dunia meningkat menjadi 28.297 jiwa (Dephub RI, 2015).

Data jumlah kecelakaan lalu lintas di Jawa Timur menurut korban pada tahun 2011 didapatkan 22.103 kasus, jumlah tersebut meningkat di tahun 2012 menjadi 24.521 kasus. Kasus kecelakaan tersebut juga diimbangi dengan jumlah korban luka ringan yang pada tahun 2011 sebanyak 25.108 kasus, kemudian meningkat menjadi 31.651 kasus pada tahun 2012 (BPS Jatim, 2015).

Tabel 1. Jumlah Kecelakaan Lalu Lintas menurut Korban di Kabupaten Sampang

\begin{tabular}{ccccc}
\hline \multirow{2}{*}{ Bulan } & Jumlah & \multicolumn{3}{c}{ Korban } \\
\cline { 2 - 5 } & Kecelakaan & MD & LB & LR \\
\hline 1 & 13 & 5 & - & 8 \\
2 & 10 & 4 & - & 6 \\
3 & 16 & 4 & - & 12 \\
4 & 12 & 5 & - & 7 \\
5 & 13 & 5 & - & 8 \\
6 & 27 & 6 & 2 & 19 \\
7 & 29 & 8 & 1 & 20 \\
8 & 20 & 6 & - & 14 \\
9 & 26 & 7 & 2 & 17 \\
10 & 18 & 7 & 1 & 10 \\
11 & 12 & 6 & 1 & 5 \\
\hline Jumlah & \multicolumn{5}{c}{} \\
\hline \multicolumn{5}{c}{196} \\
\hline
\end{tabular}

Menurut data dari Polrestabes Sampang tahun 2016 pada tabel 1, terdapat 196 kejadian kecelakaan. Sebagian besar korbannya berusia 16-30 tahun dimana rentang umur ini merupakan rentang umur produktif, yang berjumlah 64 orang. Jenis kendaraan yang paling banyak terlibat dalam kecelakaan lalu lintas yaitu sepeda motor dengan jumlah 135 kendaraan.

Tingginya jumlah kecelakaan lalu lintas disebabkan oleh beberapa faktor, namun yang paling dominan adalah faktor manusia. Pelanggaran rambu lalu lintas merupakan salah satu penyebab terjadinya kecelakaan lalu lintas. Pelanggaran tersebut diakibatkan karena kesengajaan maupun kurangnya kontrol diri pada pengemudi terhadap peraturan yang berlaku.

Pengendara sepeda motor yang melakukan pelanggaran terjadi karena rendahnya kontrol diri dari pengemudi. Sama halnya pada faktor kepribadian juga dapat memengaruhi pelanggaran sehingga dapat menyebabkan kecelakaan lalu lintas (Kusumadewi, 2012).

Tipe kepribadian terbagi menjadi dua bagian, yaitu kepribadian introvert dan 
kepribadian extrovert. Tipe kepribadian introvert cenderung menutup diri dari lingkungan sekitarnya, serta keputusan yang diambil hanya didasarkan oleh perasaan, pemikiran, dan pengalaman dari individu. Sementara untuk kepribadian extrovert, seorang anak cenderung lebih aggressive, sehingga keputusan yang diambil berdasar dari pengalaman teman sekitarnya (Notoatmojo, 2010).

Menurut penelitian Nabi et al (2005), manusia merupakan faktor terbesar yang menyumbang jumlah kecelakaan lalu lintas terbanyak. Tingkah laku pada pengemudi kendaraan bermotor yang dimaksud yaitu pelanggaran terhadap undang-undang, serta cara berkendara.

Tujuan penelitian ini untuk menganalisis hubungan antara tipe kepribadian dan pelanggaran oleh pengendara sepeda motor dengan kejadian kecelakaan lalu lintas.

\section{METODE PENELITIAN}

Penelitian mengenai tipe kepribadian dengan pelanggaran pada pengendara sepeda motor ini merupakan penelitian epidemiologi observasional analitik. Penelitian ini dipilih karena peneliti hanya melakukan pengamatan terhadap suatu subjek penelitian tanpa ada pemberian perlakuan. Penggunaan penelitian analitik ini dilakukan untuk menganalisis hubungan paparan dan outcome.

Cara mengamati status paparan dan penyakit dengan cara serentak pada satu waktu di subjek penelitian, membutuhkan sebuah rancang bangun cross sectional study. Hal itu dikarenakan penelitian ini mempelajari hubungan penyakit, yaitu kecelakaan lalu lintas dan paparan (tipe kepribadian dan pelanggaran).

Penelitian dilakukan di SMA atau sekolah yang sederajat di wilayah Kabupaten Sampang. Populasi pada penelitian ini yaitu semua siswa dari SMA atau sederajat yang berada di wilayah Kabupaten Sampang serta memenuhi kriteria inklusi. Kriteria inklusi pada populasi yang diteliti terbagi menjadi dua yaitu siswa yang merupakan pengendara sepeda motor aktif minimal dalam enam bulan terakhir, dan siswa yang sedang duduk dibangku sekolah kelas XI pada tahun ajaran 2016/2017.

Cara pengambilan sampel dilakukan secara acak (random) dengan menggunakan two stage cluster random sampling. Penggunaan teknik cluster disebabkan karena adanya unsur antar kelompok relatif homogen sedangkan unsur dalam kelompok relatif heterogen. Teknik sampling ini membutuhkan adanya list cluster berupa daftar nama SMA untuk pemilihan sampel dengan fraksi sebesar 10\% kemudian dari SMA yang telah terpilih, didapatkan 107 responden.

Variabel dalam penelitian ini terdiri dari variabel terikat dan bebas. Variabel terikat pada penelitian ini yaitu kecelakaan lalu lintas. Variabel bebas pada penelitian ini yaitu tipe kepribadian dan pelanggaran lalu lintas. Pelaksanaan penelitian dilakukan pada bulan Januari hingga bulan Juni 2017. Pengumpulan data dilakukan melalui pengisian kuesioner oleh responden secara individu. Penentuan responden yaitu sebagai pengendara sepeda motor aktif minimal dalam enam bulan terakhir, kemudian dilakukan wawancara langsung kepada responden.

Statistik deskriptif digunakan untuk menjelaskan distribusi frekuensi jenis kelamin, usia, dan kejadian kecelakaan lalu lintas. Analisis data untuk mengetahui hubungan tipe kepribadian dengan pelanggaran pengendara sepeda motor pada kejadian kecelakaan lalu lintas dilakukan dengan menggunakan uji chi square tabel kontingensi $2 \times 2$. Hubungan serta besar keterkaitan diketahui dengan membandingkan $p$ value serta melakukan perhitungan Risk Ratio dengan Confidence Interval sebesar 95\%.

\section{HASIL}

Terdapat siswa SMA di Kabupaten Sampang yang menduduki bangku kelas XI serta pernah mengalami kecelakaan lalu 
lintas saat mengendarai kendaraan bermotor khususnya sepeda motor.

Tabel 1. Frekuensi Karakteristik Responden Penelitian berdasarkan Jenis Kelamin

\begin{tabular}{ccc}
\hline Jenis kelamin & Jumlah & Presentase (\%) \\
\hline Laki-laki & 34 & 31,8 \\
Perempuan & 73 & 68,2 \\
\hline Jumlah & 107 & 100 \\
\hline
\end{tabular}

Tabel 1 menunjukkan bahwa pada karakteristik responden penelitian berdasarkan jenis kelamin adanya perbedaan jumlah yang cukup signifikan antara jenis kelamin perempuan sebagai mayoritas, dan jenis kelamin laki-laki sebagai minoritas. Hal ini cukup sebanding dengan data dari BPS Sampang yang menyatakan bahwa dari 117.250 penduduk di Sampang, penduduk terbanyak di Kabupaten Sampang yaitu penduduk berjenis kelamin perempuan dengan jumlah 59.581 penduduk, dan jenis kelamin laki-laki sebanyak 57.669 penduduk. Kemudian untuk karakteristik responden penelitian berdasarkan usia akan dijabarkan pada tabel 2 berikut.

Tabel 2. Distribusi Karakteristik Responden Penelitian berdasarkan Usia

\begin{tabular}{ccc}
\hline Jenis kelamin & Jumlah & Presentase (\%) \\
\hline 17 & 87 & 81,3 \\
$>17$ & 20 & 18,7 \\
\hline Jumlah & 107 & 100 \\
\hline
\end{tabular}

Tabel 2 menunjukkan bahwa karakteristik responden penelitian berdasarkan usia sebagian besar responden berusia 17 tahun. Siswa yang berusia 17 tahun sebagai mayoritas tersebut, dari 87 responden sebanyak 77 responden tidak memiliki Surat Ijin Mengemudi.

Distribusi karakteristik responden penelitian berdasarkan kejadian kecelakaan lalu lintas ditunjukkan pada gambar 1 berikut.

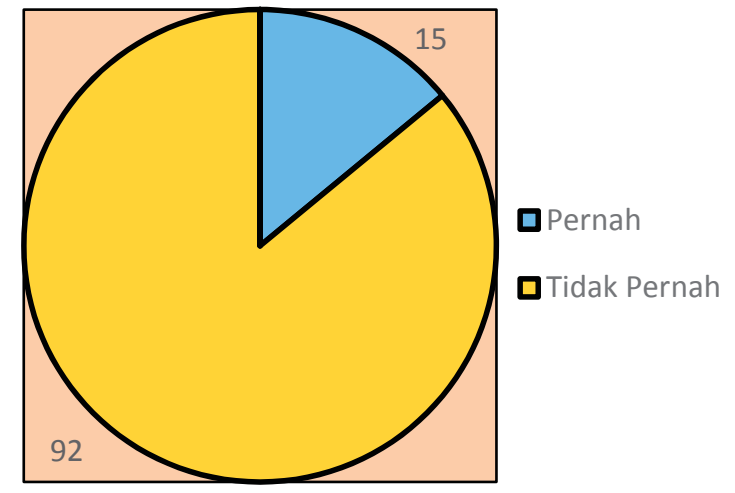

Gambar 1. Distribusi Karakteristik Responden berdasarkan Kejadian Kecelakaan Lalu Lintas.

Gambar 1 menunjukkan bahwa hampir setengah dari total responden penelitian tidak pernah mengalami kecelakaan lalu lintas. Jumlah kepemilikan SIM dapat dilihat pada tabel 3.

Tabel 3. Distribusi Karakteristik Responden berdasarkan Jumlah Kepemilikan SIM

\begin{tabular}{lcc}
\hline $\begin{array}{c}\text { Kepemilikan } \\
\text { SIM }\end{array}$ & Jumlah & $\begin{array}{c}\text { Presentase } \\
\mathbf{( \% )}\end{array}$ \\
\hline Ya & 10 & 9,3 \\
Tidak & 97 & 90,7 \\
\hline \multicolumn{1}{c}{ Jumlah } & 107 & 100 \\
\hline
\end{tabular}

Tabel 3 menunjukkan bahwa karakteristik responden berdasarkan jumlah kepemilikan SIM terdapat banyak siswa SMA di Sampang yang belum memiliki Surat Ijin Mengemudi. Terdapat 8 responden berusia 17 tahun yang sudah memiliki Surat Ijin Mengemudi, dan 2 responden berusia $>17$ tahun sudah memiliki SIM. Sementara itu untuk responden dengan usia 17 tahun yang tidak memiliki Surat Ijin Mengemudi terdapat 78 responden, dan 19 responden berusia $>17$ tahun belum memiliki Surat Ijin Mengemudi. Distribusi karakteristik responden penelitian berdasarkan waktu kecelakaan akan dijabarkan pada tabel 4 berikut. 
Tabel 4. Distribusi Karakteristik Responden Penelitian berdasarkan Waktu Kecelakaan

\begin{tabular}{ccc}
\hline $\begin{array}{c}\text { Waktu } \\
\text { Kecelakan }\end{array}$ & Jumlah & $\begin{array}{c}\text { Presentase } \\
\text { (\%) }\end{array}$ \\
\hline 2016 & 4 & 26,67 \\
2017 & 11 & 73,33 \\
\hline Jumlah & 15 & 100 \\
\hline
\end{tabular}

Tabel 4 menunjukkan hanya sebagian kecil dari responden yang pernah mengalami kecelakaan pada tahun 2017. Jumlah pada tahun 2017 dijabarkan sebanyak 2 orang mengalami kecelakaan sewaktu berangkat sekolah, 3 orang mengalami kecelakaan sepulang sekolah, dan 6 orang mengalami kecelakaan tidak pada saat hari efektif. Hasil analisis keseluruhan dapat dilihat di tabel 5 berikut, Hubungan antara variabel jenis kelamin dengan kecelakaan lalu lintas menunjukkan bahwa pada responden perempuan lebih banyak yang pernah mengalami kecelakaan lalu lintas. Namun demikian, data menunjukkan bahwa hanya 2 orang siswa laki-laki yang pernah mengalami kecelakaan lalu lintas. Pencarian hubungan pada jenis kelamin dengan kejadian kecelakaan lalu lintas menggunakan uji chi square dengan tabel kontingensi $2 \times$ 2 , kemudian menghasilkan nilai $p$ value sebesar 0,137 . Nilai tersebut lebih besar dari $\alpha=0,05$ yang berarti tidak ada hubungan antara jenis kelamin dengan kejadian kecelakaan lalu lintas pada siswa SMA di Kabupaten Sampang.

Nilai Risk Ratio pada variabel jenis kelamin adalah 0,330 . Ini berarti bahwa siswa perempuan berisiko mengalami kecelakaan lalu lintas 0,330 kali lebih besar daripada siswa laki-laki. Nilai 95\% Confidence Interval dari Risk Ratio (0,79-1,383) menunjukkan bahwa secara epidemiologi nilai tersebut tidak bermakna.

Hubungan antara variabel usia dengan kecelakaan lalu lintas menunjukkan bahwa sebanyak 14 responden berusia 17 tahun. Uji chi square dengan tabel $2 \times 2$ digunakan untuk mencari hubungan usia dengan kecelakaan lalu lintas menghasilkan nilai $p$ value sebesar 0,294 . Nilai tersebut lebih besar dibandingkan $\alpha=0,05$, yang artinya tidak ada hubungan antara variabel usia dengan kejadian kecelakaan lalu lintas pada

Tabel 5. Analisis Hubungan Jenis Kelamin, Usia, Tipe Kepribadian, Pelanggaran Rambu Lalu Lintas dengan Kecelakaan Lalu Lintas

\begin{tabular}{|c|c|c|c|c|c|}
\hline Variabel & $\begin{array}{c}\text { Pernah } \\
\text { Kecelakaan }\end{array}$ & $\begin{array}{c}\text { Tidak Pernah } \\
\text { Kecelakaan }\end{array}$ & $p$ value & $\mathbf{R R}$ & CI 95\% \\
\hline \multicolumn{6}{|l|}{ Jenis Kelamin } \\
\hline Laki-Laki & $2(5,88 \%)$ & $32(94,12 \%)$ & \multirow{2}{*}{0,137} & \multirow{2}{*}{0,330} & \multirow{2}{*}{$(0,79-1,383)$} \\
\hline Perempuan & $13(17,81 \%)$ & $60(82,19 \%)$ & & & \\
\hline \multicolumn{6}{|l|}{ Usia } \\
\hline 17 & $14(16,1 \%)$ & $73(83,9 \%)$ & \multirow{2}{*}{0,294} & \multirow{2}{*}{3,218} & \multirow{2}{*}{$(0,449-23,071)$} \\
\hline$>17$ & $1(5 \%)$ & $19(95 \%)$ & & & \\
\hline \multicolumn{6}{|l|}{ Tipe Kepribadian } \\
\hline Introvert & $1(20 \%)$ & $4(80 \%)$ & \multirow{2}{*}{0,537} & \multirow{2}{*}{1,457} & \multirow{2}{*}{$(0,236-8,987)$} \\
\hline Extrovert & $14(13,73 \%)$ & $88(86,27 \%)$ & & & \\
\hline \multicolumn{6}{|l|}{$\begin{array}{l}\text { Pelanggaran Rambu } \\
\text { Lalu lintas }\end{array}$} \\
\hline Rambu Larangan & $8(13,56 \%)$ & $51(86,44 \%)$ & \multirow{2}{*}{1} & \multirow{2}{*}{0,930} & \multirow{2}{*}{$(0,363-2,381)$} \\
\hline Marka Jalan & $7(14,58 \%)$ & $41(85,42 \%)$ & & & \\
\hline Total & & & & & \\
\hline
\end{tabular}


siswa SMA di Kabupaten Sampang pada tahun 2017.

Nilai Risk Ratio pada variabel usia adalah 3,218. Ini berarti bahwa pengendara yang berusia 17 tahun berisiko mengalami kecelakaan lalu lintas 3,218 kali lebih besar dari pada pengendara berusia $>17$ tahun. Nilai 95\% Confidence Interval dari Risk Ratio $(0,449-23,071)$ menunjukkan bahwa risiko tersebut tidak bermakna secara epidemiologi.

Hubungan antara variabel tipe kepribadian dengan kecelakaan lalu lintas menunjukkan bahwa sebagian besar responden termasuk tipe kepribadian extrovert. Tipe extrovert yang dimaksud adalah seorang anak yang lebih terbuka terhadap orang lain, dan cenderung agresif pada setiap hal yang dilakukannya. Data tipe kepribadian responden didapatkan dengan memberikan sebanyak 15 pertanyaan mengenai cara berkendara sepeda motor beserta aturan berkendara.

Pencarian hubungan tipe kepribadian dan kecelakaan lalu lintas menggunakan uji chi square dengan tabel kontingensi $2 \times 2$, menghasilkan nilai $p$ value sebesar 0,537 . Nilai tersebut lebih besar dari $\alpha=0,05$, yang berarti tidak memiliki hubungan antara tipe kepribadian dengan kejadian kecelakaan lalu lintas pada siswa SMA di Kabupaten Sampang pada tahun 2017.

Nilai Risk Ratio pada variabel tipe kepribadian adalah 1,457. Ini berarti siswa yang memiliki tipe kepribadian extrovert berisiko mengalami kecelakaan lalu lintas 1,457 kali lebih besar daripada siswa yang memiliki tipe kepribadian introvert. Nilai 95\% Confidence Interval dari Risk Ratio $(0,236-8,987)$ menunjukkan bahwa secara epidemiologi hubungan tersebut tidak memiliki makna.

Hubungan antara pelanggaran rambu lalu lintas pada pengendara sepeda motor dengan kejadian kecelakaan lalu lintas menunjukkan bahwa sebagian besar responden pernah melanggar rambu lalu lintas. Rambu lalu lintas yang sering dilanggar adalah rambu larangan. Rambu larangan yang dimaksud yaitu rambu dilarang putar balik. Data pelanggaran rambu lalu lintas oleh responden didapatkan dengan memberikan sebanyak satu pertanyaan mengenai rambu lalu lintas yang sering di langgar.

Mencari hubungan pelanggaran rambu lalu lintas dengan kejadian kecelakaan lalu lintas menggunakan uji chi square dengan tabel kontingensi $2 \times 2$ untuk menghasilkan nilai $p$ value sebesar 1 . Jika dibandingkan dengan $\alpha=0,05$ nilai tersebut cukup besar, yang berarti tidak ada hubungan antara pelanggaran rambu lalu lintas dengan kejadian kecelakaan lalu lintas pada siswa SMA di Kabupaten Sampang pada tahun 2017.

Nilai Risk Ratio pada variabel pelanggaran rambu lalu lintas adalah 0,930. Ini berarti bahwa siswa yang melanggar rambu lalu lintas larangan lebih berisiko mengalami kecelakaan lalu lintas 0,930 kali lebih besar dibandingkan dengan siswa yang melanggar marka jalan. Nilai 95\% Confidence Interval $(0,363-2,381)$ menunjukkan bahwa risiko tersebut tidak bermakna secara epidemiologi.

\section{PEMBAHASAN}

\section{Gambaran Karakteristik Responden}

Pendistribusian pada karakteristik berdasarkan jenis kelamin pada penelitian ini menunjukkan bahwa persentase siswa SMA yang menjadi pengendara sepeda motor aktif lebih banyak pada perempuan daripada laki-laki.

Banyaknya pengendara motor yang berjenis kelamin perempuan disebabkan karena adanya gaya hidup yang berbeda di mana perempuan lebih mandiri dibandingkan dengan laki-laki dalam hal berkendara. Salah satu penyebab banyaknya wanita yang menjadi korban kecelakaan lalu lintas pada saat ini yaitu selayaknya perempuan hanya menjadi penumpang namun kini perempuan 
juga dapat mengendarai kendaraan bermotor sendiri (Sarry dan Widodo, 2014).

Responden yang berusia 17 tahun merupakan masa remaja yang rentang usianya wajar untuk siswa SMA kelas XI. Menurut Hurlock (1978) dalam Mansur (2009) responden dalam penelitian ini berada pada masa remaja yang mayoritas ingin menonjolkan dirinya dan menjadikan dirinya sebagai pusat perhatian pada sekitarnya. Usia remaja ini dapat digolongkan menjadi masa remaja lanjut (17-21 tahun).

Menurut Weymen dalam Salihat dan Kurniawidjaja (2010), pengalaman mengenai risiko yang dihadapi saat berkendara, pengetahuan mengenai risiko tersebut, dan persepsi mengenai kemampuan mengendalikan risiko berbanding lurus dengan sering tidaknya seseorang mengendarai kendaraan. Perilaku safety riding pada seseorang juga salah satunya dipengaruhi oleh pengalaman dan persepsi mengenai risiko kecelakaan lalu lintas. Dengan demikian, persepsi risiko kecelakaan memiliki hubungan berbanding terbalik dengan perilaku aggressive driving (Utami, 2010).

Usia pada manusia merupakan sebuah pengaruh yang besar akan adanya kecelakaan pada sepeda motor yang kebanyakan terjadi pada anak remaja. Usia pada rentang (1720 tahun) juga berisiko untuk melakukan pelanggaran lalu lintas (Ariwibowo, 2013).

Distribusi karakteristik responden berdasarkan usia pada penelitian ini menunjukkan banyaknya pengendara sepeda motor pada usia 17 tahun. Hal tersebut menunjukkan bahwa banyak responden yang menjadi pengendara sepeda motor sesuai dengan UU No. 22 Tahun 2009 yang menyebutkan bahwa telah melarang anak usia $<17$ tahun untuk mengendarai sepeda motor.

Pasal 77 ayat 1 dalam UU angkutan jalan menyebutkan bahwa setiap orang wajib memiliki SIM bagi yang mengemudikan kendaraan bermotor, hal tersebut juga dapat disesuaikan dengan jenis kendaraan yang akan digunakan. Surat ijin atau SIM C juga merupakan syarat bagi pengendara sepeda motor. Pasal 81 ayat 2 poin a menyebutkan bahwa syarat usia seseorang untuk mendapatkan SIM C yaitu 17 tahun.

Banyaknya siswa SMA yang mengendarai sepeda motor menyatakan ragu terhadap kewajiban untuk membawa SIM saat berkendara (Notosiswoyo, 2014)

\section{Hubungan Tipe Kepribadian dengan Kejadian Kecelakaan Lalu Lintas}

Hasil analisis penelitian menunjukkan bahwa tidak ada hubungan antara tipe kepribadian dengan kejadian kecelakaan lalu lintas. Namun tidak sejalan dengan penelitian yang dilakukan sebelumnya oleh Fikri (2015), bahwa terdapat hubungan yang signifikan antara kepribadian dengan kecelakaan lalu lintas supir di Provinsi Riau. Tipe kepribadian yang berhubungan dengan kecelakaan lalu lintas adalah tipe kepribadian introvert dan tipe kepribadian extrovert.

Masyarakat dari Madura yang notabene mempunyai tingkat emosi tinggi juga termasuk dalam tipe kepribadian extrovert. Hal ini juga dapat dilihat dari cara berkendara masyarakat Madura yang kurang memperhatikan arti keselamatan berkendara. Stimulus yang diterima pada setiap orang akan menunjukkan adanya sikap serta kepribadian seseorang. Menurut Tasca, 2000 (dalam Sulistyaningsih, 2014) melaporkan bahwa faktor kepribadian yang sudah diidentifikasi dan merupakan suatu hubungan terhadap terjadinya kecelakaan pada kendaraan, pada umumnya yaitu sikap pengemudi yang kurang baik, impuls serta pengambilan risiko. Kepribadian yang akan terbentuk pada seseorang dilihat dari bagaimana seseorang tersebut dalam memiliki pengalaman.

Menurut Kurniawati (2012), kepribadian merupakan tingkah laku seseorang yang cenderung menetap dan berulang. Sebuah perilaku dapat terbentuk melalui tingkah laku serta banyaknya unsur yang terdapat dalam diri individunya. Tidak 
hanya itu hal lain yang dapat berpengaruh adalah keadaan sosial dari setiap orang serta kondisi fisik lingkungan beserta sosialnya.

Meskipun tidak terdapat hubungan antara tipe kepribadian dengan kejadian kecelakaan lalu lintas, namun kepribadian tersebut juga dapat mengundang bahaya. Hal tersebut dikarenakan sedikit banyak kepribadian seseorang tersebut bersifat "permanen", yakni tidak mudah berubah dalam waktu yang relatif singkat. Pada umumnya keadaan tersebut berupa keadaan psikologis seperti stress, cemas, bosan, dan sebagainya; dan dapat pula berupa keadaan seperti lelah, lapar, mengantuk, dan sebagainya.

Setiap individu memiliki ciri khas tersendiri dalam berperilaku, tidak hanya itu sifat yang dimiliki antara individu satu dengan individu lainnya mempunyai bentuk kepribadian yang berbeda pula. Kepedulian terhadap orang lain merupakan faktor pribadi yang telah diidentifikasi pada kecelakaan serta memiliki hubungan dengan cara mengemudikan kendaraan yang kurang baik ketika melepaskan emosional, dan pengambilan sebuah risiko (Sulistyaningsih, 2014).

Setiap individu dari kedua tipe kepribadian tersebut memiliki tingkat kecemasan yang berbeda-beda, dikarenakan oleh beberapa faktor. Kebanyakan orang dengan tipe kepribadian extrovert memiliki karakteristik yang aktif dan energik, suka bergaul, ramah, lebih banyak berbicara dibandingkan dengan mendengarkan, dan selalu membutuhkan orang lain untuk sharing. Kebanyakan dari mereka menyukai pekerjaan yang dilakukan secara berkelompok, mereka lebih menyukai pekerjaan yang dilakukan hanya untuk satu orang saja. Tidak hanya itu mereka juga merupakan individu yang meledak-ledak, dan suka menonjolkan diri dan susah dipercaya.

Sebaliknya, menurut Kurniawati (2012) seseorang dengan tipe kepribadian introvert memiliki karakteristik yang cenderung tertutup, pemalu, lebih mawas diri, sering menahan rasa senang dan sering menahan rasa emosi. Sebelum melakukan sesuatu biasanya mereka lebih banyak berencana, karena kebanyakan dari mereka kurang percaya dengan adanya faktor kebetulan. Jika ada masalah yang serius individu tersebut lebih banyak menunjukkan kecemasan, oleh karena itu mereka lebih mudah pesimis.

Menurut Wirawan (1996), kecelakaan lalu lintas melibatkan dua hal, baik faktor lingkungan maupun faktor manusia, hingga untuk menekan angka kecelakaan lalu lintas, kedua faktor itu perlu diperhitungkan. Faktor manusia terkait dengan faktor kepribadian yang sedikit bayak bersifat "permanen", dan terkait pula dengan keadaan temporer dari si pengguna jalan. Bagi pengguna jalan yang sedang dalam keadaan berisiko tinggi itu disarankan agar tidak mengendarai kendaraannya dulu sampai keadaannya kembali menjadi normal, sedangkan bagi pengguna jalan yang memiliki kepribadian pengundang bahaya, karena sifatnya yang sedikit banyak "permanen" itu, disarankan untuk berkonsultasi pada seorang psikologi (Wirawan, 1996).

\section{Hubungan Pelanggaran pada Pengendara Sepeda Motor dengan Kecelakaan Lalu Lintas}

Hasil analisis penelitian menunjukkan bahwa tidak terdapat hubungan antara pelanggaran pada pengendara sepeda motor dengan kejadian kecelakaan lalu lintas. Meski hasil yang didapat tidak berhubungan, tetapi adanya pelanggaran yang dilakukan oleh pengguna jalan sangat berpengaruh bagi pengguna jalan lainnya. Misal, adanya kecelakaan yang diakibatkan karena pengendara melanggar marka jalan seperti marka garis putih panjang yang berarti tidak boleh mendahului pengendara di depannya atau pelanggar yang melanggar rambu dilarang putar balik. Hal ini ditunjukkan dalam data yang diperoleh bahwa terdapat 15 responden yang menyatakan pernah mengalami kecelakaan lalu lintas dan pernah 
melanggar rambu lalu lintas beserta marka jalan.

Meskipun tidak terdapat hubungan antara pelanggaran yang dilakukan oleh pengendara sepeda motor, namun penggunaan jalur secara sembarangan oleh pengendara juga dapat menyebabkan kecelakaan lalu lintas. Program kanalisasi lajur, digunakan agar para pengguna jalan khususnya para pengendara kendaraan bermotor (sepeda motor), dapat lebih disiplin saat berkendara, agar tidak membahayakan pengguna jalan yang lainnya.

Setiap program pasti memiliki kendala pada pelaksanaannya. Program ini pun juga memiliki kendala pada infrastruktur yang kurang memadai serta keadaan jalan yang kurang baik. Jalan yang relatif lebar dapat mengurangi terjadinya kecelakaan lalu lintas. Program ini juga dapat berjalan dengan baik, jika jalan yang digunakan sebagai kanalisasi lajur dilengkapi dengan adanya pemisah jalur dan alat berupa separator (Sarry dan Widodo, 2014).

Banyaknya cara yang dapat digunakan untuk program ini yaitu salah satunya dengan memisahkan pengendara kendaraan bermotor sesuai dengan jenis kendaraan yang dikemudikan. Banyak hal yang dapat membahayakan para pengemudi, salah satunya kebanyakan masyarakat yang mengendarai sepeda motor lebih ugalugalan. Hal tersebut dapat digunakan sebagai pertimbangan dalam menjalankan program kanalisasi jalur yaitu dengan memisahkan jalur yaitu dengan adanya marka jalan. Marka jalan terdapat dua kategori, yaitu dapat berupa garis lurus yang tidak terputus mempunyai makna bagi pengendara agar tidak berpindah jalur, sedangkan garis putih yang terputus-putus berarti bahwa pengendara diperbolehkan berpindah jalur (Sarry dan Widodo, 2014).

Faktor utama dalam menentukan perilaku seseorang yaitu predisposisi, faktor pemungkin, dan faktor penguat. Penggunaan jalur lalu lintas bagi pengendara sepeda motor termasuk dalam faktor penentu menurut
Teori Lawrence Green. Faktor pemungkin dalam hal ini yaitu tentang adanya peraturan penggunaan jalur lalu lintas. Tidak hanya itu, hal lain yang dapat terjadi adalah adanya persepsi setiap individu mengenai bahaya akibat penggunaan jalur yang kurang sesuai, serta kurangnya pemahaman arti rambu lalu lintas dan marka jalan. Adanya marka sebagai sarana prasarana berguna untuk memisahkan antara dua lajur, yaitu lajur kiri dan kanan. Sedangkan untuk faktor penguatnya yaitu dengan adanya kebijakan-kebijakan yang telah dibuat (Notoatmodjo, 2010).

Menurut Notosiswoyo (2014), pengetahuan pada pengendara sepeda motor merupakan hubungan nyata dalam pencegahan kecelakaan. Pengetahuan yang dimaksud yaitu mengenai larangan berkendara bagi pengendara yang tidak memiliki SIM, serta melanggar tata tertib lalu lintas dalam berkendara yang benar.

Perilaku pencegahan menurut Notosiswoyo (2014), memiliki hubungan dengan pengetahuan para pengguna jalan khususnya pengendara sepeda motor. Kurangnya implementasi dalam pengetahuan oleh pengendara kendaraan bermotor dapat menyebabkan kecelakaan lalu lintas. Adanya perbedaan serta pemahaman yang dapat menimbulkan berbagai masalah lalu lintas seperti pelanggaran pada rambu lalu lintas mengakibatkan terjadinya kecelakaan lalu lintas.

\section{SIMPULAN DAN SARAN}

Kesimpulan dari penelitian ini adalah sebagian besar responden berjenis kelamin perempuan dan pernah mengalami kecelakaan lalu lintas. Responden berumur 17 tahun merupakan responden terbanyak. Kebanyakan dari mereka belum memiliki SIM atau surat ijin. Tipe kepribadian pada pengendara sepeda motor mayoritas berkepribadian extrovert, kepribadian ini cukup berbahaya jika dihubungkan dengan kejadian kecelakaan. Kemudian, untuk pelanggaran lalu lintas pengendara yang melanggar rambu larangan lebih banyak 
daripada pengendara yang melanggar marka jalan. Kedua variabel bebas yang telah diteliti tidak menunjukkan suatu hubungan yang bermakna dengan kejadian kecelakaan lalu lintas pada siswa SMA di Kabupaten Sampang 2017. Variabel yang tidak memiliki hubungan bermakna terhadap kejadian kecelakaan lalu lintas pada siswa SMA di Kabupaten Sampang pada tahun 2017 tersebut yakni tipe kepribadian $(\mathrm{p}=0,537)$ dan pelanggaran oleh pengendara sepeda motor (meliputi: rambu larangan, dan marka jalan) $(\mathrm{p}=1)$.

Perlu adanya upaya dalam meminimalisir angka kejadian kecelakaan lalu lintas yang melibatkan siswa SMA sebagai pengendara sepeda motor. Cara yang dapat dilakukan yaitu dengan mengimbau seluruh pengendara khususnya siswa SMA untuk tidak mengendarai sepeda motor sebelum memiliki SIM. Kurangnya kesiapan bagi kondisi psikis pada pengendara sepeda motor usia remaja merupakan salah satu faktor risiko terjadinya kecelakaan lalu lintas. Kurangnya pengetahuan terhadap terjadinya risiko kecelakaan pada pengguna jalan yang lainnya juga berperan bagi pembentukan perilaku pada siswa untuk pelanggaran lalu lintas pada siswa SMA dengan menjadi pengendara sepeda motor. Adanya peran orang tua guna mencegah adanya pengendara sepeda motor terutama remaja yang belum memiliki SIM juga sangat diperlukan agar dapat mendukung upaya pihak kepolisian dan sekolah dalam meminimalisir angka kejadian kecelakaan yang melibatkan siswa SMA. Penegak hukum diharapkan pula untuk lebih mempertegas peraturan mengenai larangan berkendara pada remaja usia 17 tahun yang belum memiliki SIM dan memberikan sanksi bagi orang yang melanggar, serta perlu adanya sosialisasi tentang pengetahuan rambu-rambu pada lalu lintas bagi masyarakat yang belum paham rambu lalu lintas khususnya masyarakat Madura.

\section{DAFTAR PUSTAKA}

Ariwibowo, R. 2013. Hubungan antara Umur, Tingkat Pendidikan, pengetahuan, Sikap terhadap Praktik Safety Riding Awareness pada Pengendara Ojek Sepeda Motor di kecamatan Banyumanik.<http:// download.portalgaruda.org/article.php?a rticle $=73936 \&$ val $=4700>[$ Sitasi 28 juli 2017].

BPS Provinsi Jawa Timur, 2015. Provinsi Jawa Timur Dalam Angka 2015. <http:// jatim.bps.go.id/4dm!n/pdf_publikasi/ Jawa-Timur-Dalam-Angka-2015.pdf> [Sitasi 10 Oktober 2016].

BPS Kabupaten Sampang, 2013.<https:// sampangkab.bps.go.id/index.php $>$ [Sitasi 19 Juni 2017].

Dephub, 2009.UU No. 22 tahun 2009 tentang Lalu Lintas dan Angkutan Jalan. $<$ http:// hubdat.dephub.go.id/uu/288-uu-nomor22-tahun-2009-tentang-lalu-lintas-danangkutan-jalan $>$ [Sitasi 10 Oktober 2016].

Ditjen PP dan PL. 2011.Modul Penemuan dan Tatalaksana Korban Akibat Kecelakaan Lalu Lintas Jalan.

Fikri,L.N.2015.PengaruhFaktor Kepribadian, Stres Kerja terhadap Kecelakaan Jalan Raya pada Supir Bus Di Provinsi Riau. Jurnal An-Nafs. Vol. 9, No. 3 Hal: 19073305. <http://jurnal.uir.ac.id/index.php/ JAN/article/download/404/342> [Sitasi 27 Juli 2017].

Kepmenkes No. 1116 Tahun 2003 tentang Pedoman Penyelenggaraan Sistem Surveilans Epidemiologi Kesehatan. $<\mathrm{http}$ // pdk3 mi.org/file/download/KMK\%20 No.\%201116\%20ttg\%20Pedoman\%20 Penyelenggaraan $\% 20$ Siste $\% 20$ Surveilans\%20Epidemiologi\%20 Kesehatan.pdf $>$ [Sitasi 24 juli 2017].

Kurniawati, A. (2012). Perbedaan Tingkat Kecemasan pada Remaja dengan Ciri Kepribadian Introvert dan Ekstrovert di kelas X SMA Negeri 4 Surakarta. $<$ http:// eprints.ums.ac.id/22653/12/Naskah Publikasi.pdf $>$ [Sitasi 23 Oktober 2016]. 
Kusumadewi, S., Hardjajani, T., \& Priyatama, A.N. (2012). The correlation between The Social Support of Peer Group and Self-control Towards The Obedience of The Rule in The Teenage Girls of The Assalam Modern Islamic Boarding School Sukoharjo. Surakarta: Program Studi Psikologi Fakultas Kedokteran Universitas Sebelas Maret. $<$ http:// candrajiwa.psikologi.fk.uns.ac.id/index. php/candrajiwa/article/viewFile/25/15> [Sitasi 24 Juli 2017].

Mansur, H. 2009. Psikologi Ibu dan Anak untuk Kebidanan. Jakarta: Salemba Medika.

Musen, P.H., 1994. Perkembangan dan Kpribadian Anak. Jakarta: Arcan.

Nabi, Sila, Franchois, Chiron, Lafont \& Emanuel. 2005. Type A Behavior Pattern, Risky Driving Behavior and Serious Road Traffic Accident: A Prospective Study of the Gazel Cohort.American Journal of Epidemiology. $<$ https://oup.silverchaircdn.com/oup/backfile/Content_public/ Journal/aje/170/4/10.1093/aje/kwp161/2/ kwp161.pdf $>$ [Sitasi 28 Juli 2017].

Notoatmojo, S., 2010. Promosi Kesehatan: Teori dan Aplikasi. Jakarta: PT. Rineka Cipta.

Notosiswoyo, M. 2014. Pengetahuan, Sikap, dan Perilaku Siswa SLTA dalam Pencegahan Kecelakaan Sepeda Motor di Kota Bekasi. Jurnal Ekologi Kesehatan, Vol. 13 No. 1 Hal: 1-9. <http://ejournal. litbang.depkes.go.id/index.php/jek/article/ view/3937/3774> [Sitasi 27 Juli 2017].

Polrestabes Sampang. 2016. Laporan Kecelakaan Lalu Lintas Kabupaten Sampang Tahun 2016.

Salihat, I.K., Kurniawidjaja, L.M. 2010. Persepsi Risiko Berkendara dan Perilaku Penggunaan Sabuk Keselamatan di Kampus Universitas Indonesia, Depok.
Jurnal Kesehatan Masyarakat Nasional, Vol. 4 No. 6 Hal: 275-280. <http:// jurnalkesmas.ui.ac.id/kesmas/article/ view/167/168>[Sitasi 27 Juli 2017].

Sarry, Y.P., Widodo, H. 2014. Upaya Polisi Lalu Lintas dalam Meningkatkan Kedisiplinan Berlalu Lintas Pengendara Bermotor (Studi Deskriptif terhadap Program Kanalisasi lajur Kiri pada Satlantas Polres Surabaya).Kajian Moral dan Kewarganegaraan, Vol. 2 No. 2 Hal: 564-578.<http://jurnalmahasiswa. unesa.ac.id/index.php/jurnal-pendidikankewarganegaraa/article/view/7849> [Sitasi 27 Juli 2017].

Sulistyaningsih, F., 2014. Kecelakaan dengan Aggressive driving pada Pengendara Motor di UIN Maliki Malang.<http://etheses. uin-malang.ac.id/598/6/10410017\%20 Bab\%202.pdf> [Sitasi 23 oktober 2016]. Sunarto, K. 1993. Pengantar Sosiologi. Jakarta: Lembaga Penerbit Fakultas Ekonomi UI.

Utami, N. 2010.Hubungan Presepsi Risiko Kecelakaan dengan Aggressive Driving Pengemudi Motor Remaja. Skripsi. Jakarta: Universitas Islam Negeri Syarif Hidayatullah. <http:// repository.uinjkt.ac.id/dspace/ bitstream/123456789/21696/1/ N A D I Y Y A \% 20 U T A M I - F P S . PDF $>$ [Sitasi 27 juli 2017].

WHO. 2015. Global Status Report on Road Safety 2015. Geneva: Management of Noncommunicable Diseases, Disability, Violence, and Injury Prevention (NVI). Tersedia di <http://www.who.int/ violence_injury_prevention/road_safety_ status/2015/GSRRS2015_Summary EN_final2.pdf?ua $=1>[$ Sitasi 27 Juli 2017]. 